ZOOLOGIA 32 (3): 257-259, June 2015

http://dx.doi.org/10.1590/S1984-46702015000300009

\title{
A new species of Enchenopa (Hemiptera: Membracidae) from the Brazilian Atlantic Forest
}

\author{
Frederico Lencioni-Netoํㅜ \& Albino M. Sakakibara²
}

\author{
'Centro de Estudos da Natureza, Universidade do Vale do Paraíba. Campus Villa Branca, 12327-683 Jacareí, SP, Brazil. \\ E-mail: lencioni@univap.br \\ ${ }^{2}$ Departamento de Zoologia, Universidade Federal do Paraná. Caixa Postal 19020, 81531-980 Curitiba, PR, Brazil. \\ E-mail: amsakakibara@pq.cnpq.br
}

\begin{abstract}
Enchenopa luizae sp. nov. (holotype female from Brazil, State of São Paulo, municipality of São José dos Campos, Parque Natural Municipal Augusto Ruschi at $23^{\circ} 04^{\prime} 05^{\circ} \mathrm{S}^{\prime \prime}, 45^{\circ} 56^{\prime} 22^{\prime \prime} \mathrm{W}, 06 . \mathrm{VIII.2011}$, R. La Rosa leg. deposited in DZUP) is described and diagnosed from the Atlantic Forest Vale do Paraíba, São Paulo, Brazil. The new species is very similar to Enchenopa monoceros (Germar, 1821) in overall aspects but much larger and with inconspicuous lateral secondary carinae. The fourth instar nymph is also briefly characterized.
\end{abstract}

KEY WORDS. Insecta; Membracinae; Membracini; taxonomy; treehopper.

Enchenopa Amyot \& Serville, 1843 is one of the largest genera within the treehopper tribe Membracini. The members of this genus are all morphologically similar, making the species identification very difficult. The main features that define this group are: pronotum produced anteriorly in a more or less developed horn (anterior process), ornated with a pair of strong lateral carinae that extend from the tip of the anterior process to the mid-lateral portion of the posterior process, and two to four secondary short carinae on each side of the metopidium. In some cases, the anterior process may be reduced or simply angulate, as in Leioscyta Fowler, 1894. Species of this genus, however, lack secondary carinae. Enchenopa was described by Aмyot \& Serville (1843) to include a unique species, Membracis monoceros Germar, 1821. In the catalogue of McKamEY (1998), 24 species are listed, 14 of which occur in Brazil. Subsequently, Sakakibara \& Marques (2007), Rothéa \& Creão-Duarte (2007), Strümpel \& Strümpel (2007), and Sakakibara \& Marques (2010) described six species from Brazil, respectively: Enchenopa auridorsa Sakakibara \& Marques, 2007, E. fusca Sakakibara \& Marques, 2007, E. euniceae Rothéa \& Creão-Duarte, 2007, E. minuta Rothéa \& Creão-Duarte, 2007, E. brasiliensis Strümpel \& Strümpel, 2007, and E. loranthacina Sakakibara \& Marques, 2010. Additionally, Lencioni-Neto \& SaKaKibara (2014) recorded Enchenopa beebei (Haviland, 1925) for the first time in Brazil, based on specimens from state of São Paulo. It was originally described from Guiana (Haviland 1925), and was subsequently recorded for Colombia and Venezuela (STRÜmPel \& STRÜMPeL 2014). Recently, Strümpel \& Strümpel (2014) revised Enchenopa, providing comprehensive species descriptions, identification keys, and illustrations. They recognized 116 valid species, 25 of which are found in Brazil.
In this paper, a new species is described from the Brazilian Atlantic Forest municipality of São José dos Campos, Vale do Paraíba, state of São Paulo.

\section{TAXONOMY}

\section{Enchenopa luizae sp. nov.}

\section{Figs. 1-6}

Diagnosis. Entirely black, except forewings with apical translucent whitish area close to internal angle; legs with tarsal segments yellow. Anterior pronotal process short, obtuse; lateral carinae conspicuous, extended from apex of horn to mid-lateral of posterior process; secondary carinae short and barely visible.

Measurements (in millimeters). Female. Total length 7.61; length of pronotum 6.17; length of head 1.50; width of head 2.01; distance between humeral angles 2.28; length of forewings 5.26 .

Description. Female holotype. General color dull black; forewings opaque with a whitish translucent spot at apical margins extended through part of limbus (Fig. 1); undersurface of thorax, abdomen, and legs, black, tarsi yellow.

Head triangular (Fig. 2), wider than long; eyes globose, egg-shaped in lateral view; ocelli conspicuous, closer to eyes than to each other; vertex almost flat, superior margin arched, suprantennal ledges triangular; frontoclypeus laminar, rounded apically. Pronotum, in lateral view, more or less triangular; anterior process obliquely projected above head, short, blunt, relatively wide and rounded at apex (Figs. 1, 3); median carina well marked and foliaceous; posterior process tectiform, acuminated, attaining internal angle of forewings; lateral carinae

2015 | Sociedade Brasileira de Zoologia | www.sbzoologia.org.br | www.scielo.br/zool All content of the journal, except where identified, is licensed under a Creative Commons attribution-type BY-NC. 

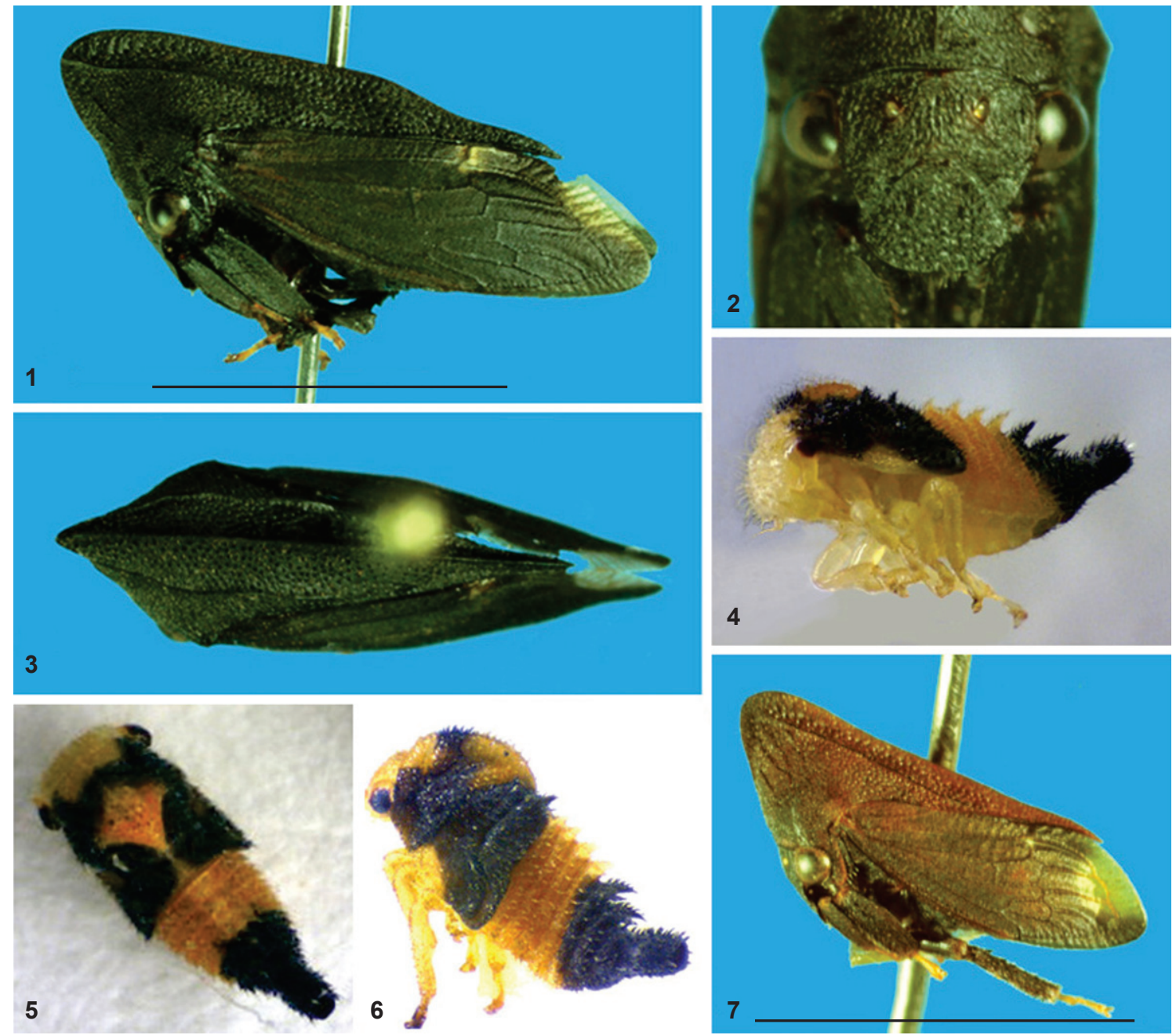

Figures 1-7. Habitus of two species of Enchenopa: (1-3) Enchenopa luizae sp. nov., female holotype in lateral, frontal and dorsal views; (4-6) nymph of the same, in ventrolateral and dorsal views; (7) Enchenopa monoceros, in lateral view. Scale bar: $5 \mathrm{~mm}$.

strong, extended from apex of anterior process to about midlateral of posterior process; secondary carinae very weak, two at each side of metopidium, barely visible (Fig. 1).

Nymph. A single nymph has been collected, probably of the fourth instar (Figs. 4-6), together with the holotype female. It closely resembles the nymphs of other species of Enchenopa. The body is somewhat recurved, with very conspicuous coloration, with yellow, whitish-yellow, and black bands. Head yellow, eyes black; pronotum, lacking anterior process, black with the posterior angle (posterior process) yellow; a black transversal band at mid-pronotum showing, in dorsal view, a yellow diamond-shaped patch; meso- and metanotum black, bearing dorsally a pair of small scoli; wing-pads yellow and black; abdomen with the basal four visible segments yellow, the rest black; all the segments with a pair of dorsal scoli, with the same color as the segments, slightly bent backward; legs yellow.
Material examined. Holotype female. "BRASIL. São Paulo:/ São José dos Campos/06-VIII-2011/Col. R. La Rosa" "P[ar]q.[ue]

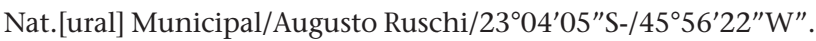
The type is deposited in the "Coleção de Entomologia Pe J. S. Moure", Departamento de Zoologia, UFPR, Curitiba, Paraná (DZUP). Additional specimen. 1 nymph (probably of fourth instar), same data as the holotype.

Etymology. The species is dedicated to Luiza Maria de Atayde Lencioni (first author's wife) for her support on his research activities.

Remarks. This new species is similar to E. monoceros (Fig. 7) in having the body entirely black, short and blunt anterior process, and opaque forewings with translucent apical spot. However, $E$. luizae sp. nov. is almost twice as large, and shows very weak secondary carinae, which are almost imperceptible; the translucent spot on the forewings is smaller, confined to the apical limbus. 
Strümpel \& Strümpel (2014) divided the genus in ten species-groups taking on account the color pattern (presence or absence of colored patch on pronotum), size of anterior process, sexual dimorphism, forewings venation, and genitalia, as follow: beebei-group, minuta-group, gladius-group, castanea-group, andinagroup, curvata-group, albidorsa-group, biplaga-group, ansera-group, and albifrons-group. Due to its characteristics, E. luizae sp. nov., belongs to andina-group, together with E. andina Schmidt, 1924, E. eurycephala Strümpel \& Strümpel, 2014, E. monoceros, E. pilosa Strümpel \& Strümpel, 2014, and E. loranthacina Sakakibara \& Marques, 2010. Using the key provided by these authors, E. luizae sp. nov. runs into the couplet 49 , keys out together with $E$. monoceros and E. andina. Below, the couplet 49 that has been modified to include the new species:

49. Forewings with yellowish-white apical patch; subapical cells approximately as long as corresponding apical cell; color dull black or dark castaneous, median carina concolor ...

$49 \mathrm{a}$

49'. Forewings without apical patch, apex dark-translucent; subapical cells as long as corresponding apical cell; color brilliant-black, median carina reddish-brown ....

E. andina Schmidt

49a. Pronotum with secondary carinae well developed; forewings apical patch occupying all distal margin and extended inward to middle of apical cells 3-4

E. monoceros (Germar)

49b. Pronotum with secondary carinae inconspicuous; forewings apical patch small, occupying only part of limbus E. luizae sp. nov.

\section{LITERATURE CITED}

Амyot CJB, A-Serville JG (1843) Histoire Naturelle des Insectes - Hémiptères. Paris, Librairie Encyclopédique de Roret, 553p.
Germar EF (1821) Bemerkungen über einige Gattungen der Cicadarien. Magazin der Entomologie 4: 1-106.

Haviland MD (1925) The Membracidae of Kartabo, Bartica District, British Guiana, with descriptions of new species and bionomical notes. Zoologica 6(3): 229-290.

Lencioni-Neto F, Sakakibara AM (2014) Registro da ocorrência de Enchenopa beebei (Haviland) (Hemiptera, Membracidae) para o Brasil. Revista Univap 20(35): 86-92.

McKamey SH (1998) Taxonomic catalogue of the Membracoidea (exclusive of leafhoppers): second supplement to fascicle I - Membracidae of the General Catalogue of the Hemiptera. Memoirs of the American Entomological Institute 60: 1377.

RothéA RRAD, Creão-Duarte AJ (2007) Duas novas espécies de Enchenopa Amyot \& Serville (Hemiptera, Membracidae) do semi-árido do Estado da Paraíba, Brasil. Revista Brasileira de Entomologia 51(1): 35-37. doi: 10.1590/S008556262007000100006

SAKakibara AM, Marques OM (2007) Espécies novas de Membracidae (Hemiptera, Cicadomorpha) coletadas em um agroecossistema cacaueiro da região sul da Bahia, Brasil. Magistra 19(1): 8287.

SaKakibara AM, Marques OM (2010) Uma nova espécie de membracídeo (Hemiptera, Membracidae) coletada em plantas da família Loranthaceae. Magistra 22(2): 134-136.

StrüMPel H, StrüMPel R (2007) Eine neue Art der Gattung Enchenopa Amyot \& Serville, 1843 (Hemiptera: Membracidae: Membracinae) aus Brasilien. Entomologische Mitteilungen aus dem Zoologischen Museum Hamburg 14(177): 421-427.

Strümpel H, Strümpel R (2014). Revision der amerikanischen Membracidengattung Enchenopa (Hemiptera: Auchenorrhyncha: Cicadomorpha: Membracidae) mit Beschreibungen neuer Arten. Entomologische Mitteilungen aus dem Zoologischen Museum Hamburg 17(191): 1-137.

Submitted: 10 February 2015

Received in revised form: 13 May 2015

Accepted: 1 June 2015

Editorial responsibility: Ângelo Parise Pinto 